\title{
Hepatic detoxification of ammonia in the ovine liver: possible consequences for amino acid catabolism
}

\author{
BY G. E. LOBLEY', A. CONNELL', M. A. LOMAX ${ }^{2}$, D. S. BROWN¹, E. MILNE ${ }^{1}$, \\ A. G. CALDER ${ }^{1}$ AND D. A. H. FARNINGHAM ${ }^{1}$ \\ ${ }^{1}$ Rowett Research Institute, Bucksburn, Aberdeen AB2 $9 S B$ \\ ${ }^{2}$ Department of Biochemistry and Physiology, University of Reading, Reading RG6 $2 A H$
}

(Received 25 April 1994-Revised 2 August 1994-Accepted 24 August 1994)

\begin{abstract}
The effects of either low $(25 \mu \mathrm{mol} / \mathrm{min})$ or high $(235 \mu \mathrm{mol} / \mathrm{min})$ infusion of $\mathrm{NH}_{4} \mathrm{Cl}$ into the mesenteric vein for $5 \mathrm{~d}$ were determined on $\mathrm{O}_{2}$ consumption plus urea and amino acid transfers across the portaldrained viscera (PDV) and liver of young sheep. Kinetic transfers were followed by use of ${ }^{15} \mathrm{NH}_{4} \mathrm{Cl}$ for $10 \mathrm{~h}$ on the fifth day with simultaneous infusion of $\left[1{ }^{13} \mathrm{C}\right.$ leucine to monitor amino acid oxidation. Neither PDV nor liver blood flow were affected by the additional $\mathrm{NH}_{3}$ loading, although at the higher rate there was a trend for increased liver $\mathrm{O}_{2}$ consumption. $\mathrm{NH}_{3}-\mathrm{N}$ extraction by the liver accounted for $64-70 \%$ of urea- $\mathrm{N}$ synthesis and at the lower infusion rate the additional $\mathrm{N}$ required could be more than accounted for by hepatic removal of free amino acids. At the higher rate of $\mathrm{NH}_{3}$ administration additional sources of $\mathbf{N}$ were apparently required to account fully for urea synthesis. Protein synthesis rates in the PDV and liver were unaffected by $\mathrm{NH}_{3}$ infusion but both whole-body $(P<0.05)$ and splanchnic tissue leucine oxidation were elevated at the higher rate of administration. Substantial synthesis of $\left[{ }^{15} \mathrm{~N}\right]$ glutamine occurred across the liver, particularly with the greater $\mathrm{NH}_{3}$ supply, and enrichments exceeded considerably those of glutamate. The $\left[{ }^{15} \mathrm{~N}\right]$ urea synthesized was predominantly as the single labelled, i.e. $\left[{ }^{14} \mathbf{N}^{15} \mathrm{~N}\right.$ ], species. These various kinetic data are compatible with the action of ovine hepatic glutamate dehydrogenase $(E C$ 1.4.1.2) in periportal hepatocytes in the direction favouring glutamate deamination. Glutamate synthesis and uptake is probably confined to the perivenous cells which do not synthesize urea. The implications of $\mathrm{NH}_{3}$ detoxification to the energy and $\mathrm{N}$ metabolism of the ruminant are discussed.
\end{abstract}

Ammonia: Ureagenesis: Liver: Amino acids: Sheep

During growth, conversion of feed- $\mathrm{N}$ into animal protein is a relatively inefficient process in all mammals, including ruminants (Lobley, 1992), with a substantial portion eliminated as urea synthesized in the liver. There are several roles for ureagenesis, including removal of amino acid-N surplus to anabolic requirements (see Meijer et al. 1990) and regulation of acid-base balance (Atkinson \& Bourke, 1984). One additional function involves removal of gastrointestinal-tract (GIT)-derived $\mathrm{NH}_{3}$ such that the peripheral concentrations are sufficient to provide substrate for reactions such as synthesis of nucleic acid bases but below those toxic to the central nervous system (Summerskill \& Wolpert, 1970). $\mathrm{NH}_{3}$ removed from the portal vein by the liver enters the ornithine (urea) cycle directly by condensation with mitochondrial $\mathrm{CO}_{2}$ to form carbamoyl phosphate under the regulated action of carbamoyl phosphate synthetase (CPS; EC 6.3.4.16; reviewed by Meijer et al. 1990). This only supplies one $\mathrm{N}$ atom to urea with the other contributed by cytoplasmic aspartate. The immediate $\mathrm{N}$-donor to aspartate is probably glutamate which is involved in a wide range of transamination reactions and although, in theory, many metabolites may contribute to urea synthesis probably only amino acids are absorbed in quantities sufficient to provide the additional $\mathrm{N}$. 
$\mathrm{NH}_{3}$-stimulated ureagenesis may, therefore, require input of amino acid- $\mathrm{N}$ with consequent penalties on protein gain. Some evidence to support this comes from studies where the relationships between urea production and hepatic removal of $\mathrm{NH}_{3}$ and amino acids have been compared. In cattle, for example, the potential contribution of extracted $\mathrm{NH}_{3}-\mathrm{N}$ to urea-N release ranges from 0.27 to 0.88 (Wilton et al. 1988; Fitch et al. 1989; Huntington, 1989; Maltby et al. 1991; Reynolds et al. 1991 b) while in response to increased $\mathrm{NH}_{3}$ extraction more free amino acids are apparently removed by the liver, with the quantities involved either sufficient (Huntington, 1989), inadequate (Reynolds et al. 1991 b) or in excess (Maltby et al. 1991) as supplies of the additional $\mathrm{N}$ for ureagenesis. For cattle fed on rations based largely on forages there is greater portal absorption and hepatic removal of $\mathrm{NH}_{3}$ which is accompanied by extra extraction of amino acids across the liver (Huntington, 1989; Maltby et al. 1991; Reynolds \& Tyrrell, 1991; Reynolds et al. 1991 b). Such a mechanism may contribute to the poorer $\mathrm{N}$ retention often observed for ruminants offered roughage as opposed to concentrate diets.

With the exception of Wilton et al. (1988), however, all the above experiments have involved changes in either diet quality or quantity and, thus, factors other than $\mathrm{NH}_{3}$ absorption may have been altered. Furthermore, these results are based on mass transfers across the liver and do not necessarily reflect the actual movement and fate of $\mathrm{NH}_{3}-\mathrm{N}$. Thus the greater hepatic uptake of amino acids in response to increased $\mathrm{NH}_{3}$ removal may not automatically result in elevated amino acid catabolism because return to the circulation as other forms, e.g. peptides, proteins, oxo-acids, may occur.

It is also possible for $\mathrm{NH}_{3}-\mathrm{N}$ to be transferred to aspartate, and thus contribute both $\mathrm{N}$ atoms to urea, by, for example, the action of glutamate dehydrogenase (GLDH; $E C$ 1.4.1.2; amination of 2-oxoglutarate) and under such circumstances the need to invoke additional $\mathrm{N}$ (from amino acids) would be unnecessary. Were this or similar mechanisms to occur then, following administration of an ${ }^{15} \mathrm{NH}_{3}$ source, the relative fluxes of $\mathrm{NH}_{3}-\mathrm{N}$ transfer into urea can be assessed from the $\left[{ }^{14} \mathrm{~N}^{14} \mathrm{~N}\right]:\left[{ }^{15} \mathrm{~N}^{15} \mathrm{~N}\right]$ urea ratios produced. On the other hand, if $\mathrm{NH}_{3}$ detoxification does require net input from essential amino acids then associated irreversible oxidation of their $\mathrm{C}$ skeletons should occur with a consequent penalty on peripheral protein anabolism. The present study examines the hypotheses that, first, $\mathrm{NH}_{3}$ detoxification in sheep involves catabolism of amino acids by examining oxidation of $\left[1-{ }^{13} \mathrm{C}\right]$ leucine and, second, that the claimed normal direction of the GLDH reaction, towards 2-oxoglutarate formation, precludes the synthesis of urea in which both $\mathrm{N}$ atoms are derived from $\mathrm{NH}_{3}$. The experimental model involves sheep offered a pelleted lucerne (Medicago sativa) diet with chronic supply of $\mathrm{NH}_{3}$ to the liver augmented by $50 \%$ through intramesenteric vein infusion. Consequent changes in bioenergetics plus the net mass and isotopic transfers of ${ }^{15} \mathrm{NH}_{3}$ and products were monitored.

\section{MATERIALS AND METHODS}

\section{Animals and surgical preparations}

Four Suffolk cross wether lambs (30-35 kg live weight (LW), 6-9 months old) were prepared with indwelling catheters in the aorta, portal, hepatic and mesenteric (2) veins under general anaesthesia with halothane-nitrous oxide. Briefly, the surgical procedure followed that described by Katz \& Bergman (1969 a) except that the hepatic portal vein catheter was inserted via the liver similar to the hepatic vein procedure and thus was retrograde to the flow. For the mesenteric vein catheters direct insertion by the Herd \& Barger (1964) method, as modified by Fleet \& Mepham (1983), was performed. All catheters were a combination of silicone rubber for the portion inside the vessels and polyvinyl chloride (PVC), thereafter. This reduced thrombogenicity and yet avoided the 
diffusion of gases which occurs with porous silicone rubber when exteriorized. Full details of the surgical procedure and catheter preparation are available on request. Catheters were sterilized with ethylene oxide before surgery. Sheep were allowed 3 weeks recovery before commencement of experimental observations and during this period appropriate veterinary treatment of antibiotics and analgesics was administered. Catheters (PVC) were inserted into each external jugular vein as described previously (Harris et al. 1992) before each experimental period.

\section{Diets and design}

Animals were adjusted to metabolism cages and offered $800 \mathrm{~g}$ lucerne pellets/d (10.5 MJ metabolizable energy $/ \mathrm{kg}$ dry matter (DM); $25 \mathrm{~g} \mathrm{~N} / \mathrm{kg} \mathrm{DM} ; \mathrm{DM}=0.89$ ), supplied as twenty-four $1 \mathrm{~h}$ portions from automated feeders.

For each sheep the design involved $5 \mathrm{~d}$ of a low $\mathrm{NH}_{4} \mathrm{Cl}$ infusion $(0.4 \mathrm{M} ; 25 \mu \mathrm{mol} / \mathrm{min})$ into the mesenteric vein. This was followed after $3 \mathrm{~d}$ by a $5 \mathrm{~d}$ high $\mathrm{NH}_{4} \mathrm{Cl}$ infusion $(2.5 \mathrm{M}$; $235 \mu \mathrm{mol} / \mathrm{min})$. Measurement of ${ }^{15} \mathrm{NH}_{3}$ and $\left[1-{ }^{13} \mathrm{C}\right]$ leucine kinetics were performed on day 5 of each level of infusion. The low and high $\mathrm{NH}_{4} \mathrm{Cl}$ infusions represented approximately 0.06 and 0.55 of estimated $\mathrm{NH}_{3}$ absorption across the GIT. The design was not randomized because of initial uncertainty as to catheter patency under the increased $\mathrm{NH}_{3}$ supply.

On the fifth day the natural abundance $\mathrm{NH}_{4} \mathrm{Cl}$ infusate was replaced by a solution containing sodium $p$-aminohippurate (PAH; $8 \mathrm{~g} / 200 \mathrm{ml}$ ) plus either, for the low $\mathrm{NH}_{3}$ infusion, $0.9 \mathrm{~g}^{15} \mathrm{NH}_{4} \mathrm{Cl}$ (98.4 atoms \%; Isotec Inc., Miamisburg, OH, USA) or, for the high $\mathrm{NH}_{3}$ infusion, $1.86 \mathrm{~g}$ enriched plus $6.05 \mathrm{~g}$ natural abundance $\mathrm{NH}_{4} \mathrm{Cl}$ for the first two sheep. These amounts were adjusted to $0.96 \mathrm{~g}$ and $6.95 \mathrm{~g}$ for the higher rate of infusion for the latter pair of animals on the grounds of economy; it had been established that adequate enrichments of the main metabolites would still be achieved. These solutions were infused for $10 \mathrm{~h}(20 \mathrm{~g} / \mathrm{h})$. At the same time $200 \mathrm{~g}$ of a solution containing $0.5 \mathrm{~g}\left[1-{ }^{13} \mathrm{C}\right]$ leucine (99 atoms \%, Tracer Technologies Ltd, Somerville, MA, USA) and 50000 IU sodium heparin in sterile saline $(9 \mathrm{~g} \mathrm{NaCl} / 1)$ was infused into the jugular vein, also at a rate of $20 \mathrm{~g} / \mathrm{h}$.

Blood samples were withdrawn continuously between 5 and $9 \mathrm{~h}$ of stable isotope infusion from the aorta, hepatic and portal veins by means of a peristaltic pump set to collect at $10 \mathrm{ml} / \mathrm{h}$. The collection lines were passed through ice, to reduce risk of coagulation, and blood pumped directly into $10 \mathrm{ml}$ syringes stored in ice-water. Samples were collected hourly.

Measurements of respiratory gas exchange under the basal dietary conditions were performed in an automated confinement respiration chamber (Blaxter et al. 1972) over three successive days and within $7 \mathrm{~d}$ of the second infusion period.

\section{Analytical measurements}

The contents of each syringe were mixed thoroughly by hand-rolling before any sample removal. Blood $\mathrm{pH}, \mathrm{pCO}_{2}, \mathrm{pO}_{2}$ and haemoglobin concentration were measured immediately with a Radiometer ABL3 Blood Gas Analyzer (Radiometer, Copenhagen, Denmark) and packed cell volume was determined by haematocrit. Two $0.7 \mathrm{ml}$ portions were then stored for measurement of blood $\mathrm{CO}_{2}$ enrichment, as described previously (Harris et al. 1992). Blood ( $5 \mathrm{ml}$ ) was then centrifuged at $1300 \mathrm{~g}$ for $15 \mathrm{~min}$ to prepare plasma. $\mathrm{NH}_{3}$ concentration in plasma was determined enzymically (Mondzac et al. 1965) using a Kone Dynamic Selective Analyzer (Kone Instruments, Espoo, Finland). All subsequent operations were then performed gravimetrically. To $1 \mathrm{~g}$ blood was added $11.5 \mathrm{~g}$ trichloroacetic acid $(100 \mathrm{~g} / \mathrm{l})$ and this was analysed for PAH (Harris et al. 1992) and involved an acid deacetylation step at $90^{\circ}$ for $2 \mathrm{~h}$. The completeness of the reaction was confirmed by tests with synthesized $N$-acetyl-PAH (results not shown). 
The remaining blood was then haemolysed by the addition of an equal weight of a solution of $300 \mu \mathrm{M}$-L-norleucine and $30 \mu \mathrm{M}-4$-methyl-2-oxo-pentanoate (MOP). $\mathrm{NH}_{3}$ concentration and enrichment were determined by a procedure similar to that of Nissim et al. (1985). The glutamate content, and thus the amount of $\mathrm{NH}_{3}$ present in the blood sample, was determined, relative to the known additions of L-norleucine and L-aspartate, by HPLC analysis based on pre-column derivatization with $o$-phthalylaldehyde (Turnell \& Cooper, 1982) of $0.25 \mathrm{ml}$ of the extract while the remainder was used for enrichment analysis by gas chromatography-mass spectrometry (GCMS). Urea concentrations were determined on the haemolysed blood by a Technicon automated procedure based on that of Marsh et al. (1965). Approximately 1.4 g haemolysed blood was freeze-dried and then resuspended in $0.5 \mathrm{ml} 70 \mathrm{~g} / 1$ sulphosalicylic acid, centrifuged and the supernatant fraction clarified through $0.22 \mu \mathrm{m}$ nylon filters using a microcentrifuge filter system (Sigma Chemical Co., Poole, Dorset). Approximately $80 \mu$ filtrate was analysed for amino acid concentration using an Alpha Plus Amino Acid Analyzer (Pharmacia-LKB Biochrom Ltd, Cambridge, Cambs) using lithium citrate buffers appropriate for analysis of physiological fluids. All values were corrected to the initial gravimetric addition of L-norleucine. Results are not presented for glycine as the high concentration in blood $(600 \mu \mathrm{M})$ saturated the ninhydrin reaction at loadings preferred for the other amino acids. The arginine values also need to be treated with caution as arginase $(E C$ 3.5.3.1) activity released from within the erythrocyte by haemolysis causes rapid reduction in the concentration of that amino acid.

Determinations of enrichment (as molar \% excess; $\mathrm{mpe}$ ) of blood ${ }^{13} \mathrm{CO}_{2}$ by isotope-ratiomass-spectrometry and leucine and MOP by GCMS were as reported previously (Harris et al. 1992). From the same blood sample used for leucine analysis the enrichments of urea, aspartate, alanine, glutamate, serine and glycine were analysed as the M-57 fragments from tertiary butyldimethylsilyl derivatives on a Hewlett Packard 5989A MS Engine (Hewlett Packard, Avondale, PA, USA). Enriched standards were prepared from both $\left[{ }^{13} \mathrm{C}\right]$ and $\left[{ }^{15} \mathrm{~N}_{2}\right]$ urea (99 atoms \% ; MSD Isotopes, Montreal, Canada) and appropriate correction factors determined for the additional contribution to $\mathrm{m}+2 \mathrm{~m} / \mathrm{z}$ ions expected from increases in the $\mathrm{m}+1$ ion. Calibrations for the amino acids were based on standards

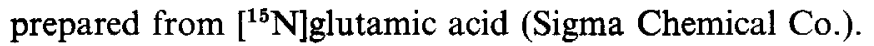

\section{Calculations and statistics}

Blood flow (BF) was calculated as described by Katz \& Bergman (1969b), corrected where necessary to plasma flow (PF) based on packed cell volume. Blood $\mathrm{O}_{2}$ content was calculated from haemoglobin content and saturation, the latter derived from equations based on the data of Bartels \& Harms (1959) for sheep. Plasma bicarbonate concentration was calculated from $\mathrm{pH}$ and $\mathrm{pCO}_{2}$ data (Siggaard-Anderson, 1974).

Mass transfers of metabolites, $\mathrm{M}$, across the PDV blood circulation (or plasma by use of PF rather than BF) were calculated from

$$
\left(\mathrm{M}_{p}-\mathrm{M}_{a}\right) \times \mathrm{BF}_{p v}
$$

where the subscripts $a$ and $p$ represent concentrations related to the artery or portal vein respectively and $p v$ is portal-vein flow. Positive values indicate net appearance into the portal circulation and negative values represent removal by the PDV tissues.

Similarly hepatic mass transfers were calculated from

$$
\left(\mathrm{M}_{h} \times \mathrm{BF}_{h v}\right)-\left(\mathrm{M}_{p} \times \mathrm{BF}_{p v}\right)-\left(\mathrm{M}_{a} \times \mathrm{BF}_{h a}\right),
$$

where $h$ represents hepatic vein concentration and $h v$ and $h a$ are the flows in the hepatic vein and artery respectively. 
Net isotope movements were determined across the PDV and liver by respectively

and

$$
\left(\mathrm{M}_{p} \times \mathrm{E}_{p}-\mathrm{M}_{a} \times \mathrm{E}_{a}\right) \times \mathrm{BF}_{p v}
$$

$$
\left(\mathrm{M}_{h} \times \mathrm{E}_{h} \times \mathrm{BF}_{h v}\right)-\left(\mathrm{M}_{p} \times \mathrm{E}_{p} \times \mathrm{BF}_{p v}\right)-\left(\mathrm{M}_{a} \times \mathrm{E}_{a} \times \mathrm{BF}_{h a}\right),
$$

where $E$ is the enrichment of the metabolite (as mpe above the background natural abundance sample) in the appropriate blood sample.

Protein synthesis calculations based on leucine kinetics followed the principles used by Harris et al. (1992) for whole-body irreversible loss rate (ILR; flux) and tissue transfers. Because the isotope infusions were conducted separately from the respiration chamber measurements there was no direct determination of whole-body leucine oxidation (Harris et al. 1992). Instead the increase in arterial blood bicarbonate mpe during the infusion was multiplied by whole-body $\mathrm{CO}_{2}$ production to give an estimate of the fraction of the infused leucine that was oxidized and this was then used to partition ILR into that due to amino acid oxidation and, by difference, that for protein synthesis (Harris et al. 1992). Across the PDV and liver the net isotope transfers from the blood for MOP and for plasma $\mathrm{CO}_{2}$ were each subtracted from that for leucine for each tissue, i.e. for PDV tissues

$$
=\left(\mathrm{L}_{p} \times \mathrm{E}_{l p}-\mathrm{L}_{a} \times \mathrm{E}_{l a}\right)-\left(\mathrm{O}_{p} \times \mathrm{E}_{o p}-\mathrm{O}_{a} \times \mathrm{E}_{o a}\right) \times \mathrm{BF}-\left(\mathrm{C}_{p} \times \mathrm{E}_{c p}-\mathrm{C}_{c a} \times \mathrm{E}_{c a}\right) \times \mathrm{PF},
$$

where $\mathrm{L}_{(\mathrm{l})}, \mathrm{O}_{(0)}$ and $\mathrm{C}_{(\mathrm{c})}$ represent leucine, MOP and $\mathrm{CO}_{2}$ concentrations (enrichments) respectively. Respiratory quotient values across the liver were below theoretical physiological limits due to loss of hepatic bicarbonate as urea $\mathrm{C}$ and in bile fluids so $\mathrm{CO}_{2}$ exchange was calculated from $0.9 \times \mathrm{O}_{2}$ uptake. For liver net isotope transfers

$$
\begin{aligned}
= & \left(\mathrm{L}_{h} \times \mathrm{E}_{l h}+\mathrm{O}_{h} \times \mathrm{E}_{o h}\right) \times \mathrm{BF}_{h}-\left(\mathrm{L}_{p} \times \mathrm{E}_{l p}+\mathrm{O}_{p} \times \mathrm{E}_{o p}\right) \times \mathrm{BF} \\
& -\left(\mathrm{L}_{a} \times \mathrm{E}_{l a}+\mathrm{O}_{a} \times \mathrm{E}_{o a}\right) \times \mathrm{BF}_{a}-\left(\mathrm{C}_{h} \times \mathrm{E}_{c h} \times \mathrm{PF}_{h}-\mathrm{C}_{p} \times \mathrm{E}_{c p} \times \mathrm{PF}_{p}-\mathrm{C}_{a} \times \mathrm{E}_{c a} \times \mathrm{PF}_{a}\right) .
\end{aligned}
$$

The resultant figure was divided by the free leucine enrichment in either the arterial blood or that of free leucine or MOP in the appropriate venous drainage (portal or hepatic vein respectively) to provide estimates of tissue protein synthesis. The sections of the above equations involving $\mathrm{CO}_{2}$ when divided by the enrichment of MOP in portal or hepatic venous blood provided estimates of leucine oxidation across the PDV and liver respectively.

Data were subjected to analysis of variance, with animals treated as blocks, for the effect of rate of $\mathrm{NH}_{3}$ administration. All data were complete (eight values) for all the main measurements but only three residual degrees of freedom were available with the design adopted. This should be borne in mind when biological trends, rather than statistically significant data, are discussed.

\section{RESULTS}

\section{Catheter patency}

No problems were encountered with the health of the animals during the study and all completed the experiments on schedule. The most troublesome catheter was that in the more distal part of the mesenteric vein and which remained patent throughout for only one sheep. The other catheter in this vessel always remained operative, however, and was therefore used as necessary in the other animals for infusion of $\mathrm{NH}_{4} \mathrm{Cl}$ and $\mathrm{PAH}$. Because the data for mesenteric-drained viscera (MDV) are incomplete these are excluded from the current presentation. In one other animal the portal vein catheter caused occasional problems and this appeared to be related to posture because if the sheep was maintained standing, by means of a loose body sling, continuous sampling was possible. At postmortem the tip of this catheter was discovered to have a thrombus alongside and in one other animal a similar, but smaller, reaction was noted. This may be related to the 
Table 1. Effect of $4 d$ chronic low $(25 \mu \mathrm{mol} / \mathrm{min})$ or high $(235 \mu \mathrm{mol} / \mathrm{min})$ infusion of ammonium chloride into the mesenteric vein of four lambs fed with $800 \mathrm{~g}$ lucerne pellets/d on arterial blood $\mathrm{pH}, \mathrm{pCO}_{2}$, bicarbonate concentration and on blood flow and oxygen consumption across the portal-drained viscera (PDV) and the liver*

\begin{tabular}{|c|c|c|c|c|}
\hline & Low $\mathbf{N H}_{\mathbf{3}}$ & High $\mathrm{NH}_{3}$ & SED & $P \dagger$ \\
\hline $\begin{array}{l}\text { Arterial blood vari } \\
\text { ph } \\
\mathrm{pCO}_{2}(\mathrm{~mm} \mathrm{Hg}) \\
{\left[\mathrm{HCO}_{3}\right](\mathrm{mm})}\end{array}$ & $\begin{array}{l}7 \cdot 444 \\
33 \cdot 4 \\
26 \cdot 3\end{array}$ & $\begin{array}{l}7 \cdot 364 \\
33 \cdot 2 \\
21 \cdot 6\end{array}$ & $\begin{array}{l}0.0114 \\
2 \cdot 80 \\
2 \cdot 28\end{array}$ & $\begin{array}{l}0.006 \\
0.937 \\
0.131\end{array}$ \\
\hline $\begin{array}{l}\text { Blood flows }(\mathrm{g} / \mathrm{min} \\
\text { Portal vein } \\
\text { Hepatic vein } \\
\text { Hepatic artery }\end{array}$ & $\begin{array}{r}1648 \\
1681 \\
33\end{array}$ & $\begin{array}{r}1696 \\
1804 \\
108\end{array}$ & $\begin{array}{r}136 \cdot 0 \\
223 \cdot 7 \\
91 \cdot 6\end{array}$ & $\begin{array}{l}0.750 \\
0.621 \\
0.621\end{array}$ \\
\hline $\begin{array}{l}\text { Oxygen consumpti } \\
\text { PDV } \\
\text { Liver }\end{array}$ & $\begin{array}{l}1.67 \\
1.54\end{array}$ & $\begin{array}{l}1.69 \\
1.84\end{array}$ & $\begin{array}{l}0.157 \\
0.422\end{array}$ & $\begin{array}{l}0.920 \\
0.535\end{array}$ \\
\hline $\begin{array}{l}\% \text { Whole-body } \mathrm{O}_{2} \\
\text { PDV } \\
\text { Liver }\end{array}$ & $\begin{array}{l}20.4 \\
19.3\end{array}$ & $\begin{array}{l}23 \cdot 0 \\
26 \cdot 1\end{array}$ & $\begin{array}{l}1 \cdot 53 \\
4.31\end{array}$ & $\begin{array}{l}0.238 \\
0.255\end{array}$ \\
\hline
\end{tabular}

SED, Standard error of the difference between means.

* For details of procedures, see pp. 668-670.

$\dagger$ Based on one-way analysis of variance, 3 residual degrees of freedom.

$\ddagger$ Calculated from $\mathrm{pO}_{2}$ and blood haemoglobin content (see p. 670).

$\$$ Whole-body oxygen uptake from respiration chamber measurement.

positioning of the catheter against the flow because in all four sheep the hepatic vein catheter was impeccable and no signs of reaction were observed at post-mortem examination. One advantage of the method of portal catheter insertion was that it was positioned in the tributary of the sampled lobe and would reduce the possibility of streaming and consequent non-mixing effects of direct insertion into the common portal vein. The surgical procedure adopted also meant that portal and hepatic vein catheters were in the same lobe of the liver.

\section{Blood variables and gaseous exchange}

Blood flows were unaltered by the $\mathrm{NH}_{4} \mathrm{Cl}$ loading (Table 1) and the mean portal vein flows were, at $49 \mathrm{~g} / \mathrm{min}$ per $\mathrm{kg} \mathrm{LW}$ and $118 \mathrm{~g} / \mathrm{min}$ per $\mathrm{kg} \mathrm{LW}^{0.75}$, similar to those reported for sheep fed close to maintenance level $(32-43 \mathrm{ml} / \mathrm{min}$ per $\mathrm{kg} \mathrm{LW}, 80-118 \mathrm{ml} / \mathrm{min}$ per $\mathrm{kg}$ LW ${ }^{0.75}$; Katz \& Bergman, 1969 b; Webster et al. 1975; Pell et al. 1986; Burrin et al. 1989; Ortigues et al. 1994). The contribution of the hepatic artery to hepatic venous flow was lower, at an average of $4 \%$ (range 0.5 to $12 \%$ ), than observed in other studies $(12-22 \%$; Katz \& Bergman, 1969 b; Pell et al. 1986; Burrin et al. 1989; Ortigues et al. 1994). If the deacetylation step was omitted then portal flow was unaltered but hepatic venous flow increased and thus the arterial contribution was raised to a greater and more consistent value of $20 \%$ (results not shown). Arterial and portal venous blood samples showed a mean increase of $16 \%$ in chromaphore after deacetylation by hot acid treatment, but with a slightly larger elevation $(19 \%)$ for the hepatic venous samples. This is greater than the 8 and $12 \%$ changes observed by Katz \& Bergman (1969 b) but consistent with their finding of substantial hepatic synthesis and release of $\mathrm{N}$-acetyl-PAH, which is insensitive to the Bratton-Marshall reaction (Smith et al. 1945). It should be noted that initial analyses based 
Table 2. Effect of $4 d$ chronic low $(25 \mu \mathrm{mol} / \mathrm{min})$ or high $(235 \mu \mathrm{mol} / \mathrm{min})$ infusion of ammonium chloride in the mesenteric vein of four lambs fed with $800 \mathrm{~g}$ lucerne pellets/d on whole-body and splanchnic tissue leucine and protein metabolism*

\begin{tabular}{|c|c|c|c|c|}
\hline & Low $\mathrm{NH}_{3}$ & High $\mathrm{NH}_{3}$ & SED & $P \dagger$ \\
\hline \multicolumn{5}{|l|}{ Whole-body kinetics } \\
\hline Arterial leucine $(\mu \mathrm{mol} / \mathrm{l})$ & 155 & 149 & 3.7 & $0 \cdot 178$ \\
\hline \multirow{2}{*}{ Flux $\ddagger(\mu \mathrm{mol} / \mathrm{min})$} & $99 \cdot 3$ & $100 \cdot 5$ & $4 \cdot 02$ & 0.895 \\
\hline & $(103-3)$ & $(103 \cdot 7)$ & (4-14) & 0.938 \\
\hline \multirow[t]{2}{*}{ Leucine oxidation $\S(\mu \mathrm{mol} / \mathrm{min})$} & $17 \cdot 3$ & $20 \cdot 4$ & 0.57 & 0.032 \\
\hline & $82 \cdot 1$ & $80 \cdot 2$ & $3 \cdot 27$ & 0.971 \\
\hline \multirow{2}{*}{$\begin{array}{l}\text { Protein synthesis }{ }^{\prime}(\mu \mathrm{mol} / \mathrm{min}) \\
(\mathrm{g} / \mathrm{d})\end{array}$} & $82 \cdot 1$ & $80 \cdot 2$ & $3 \cdot 27$ & 0.971 \\
\hline & $(235)$ & $(229)$ & & \\
\hline \multicolumn{5}{|c|}{ Splanchnic leucine kinetics $(\mu \mathrm{mol} / \mathrm{min}) \top$} \\
\hline \multicolumn{5}{|l|}{ Net leucine transfers } \\
\hline PDV & 23.9 & $23 \cdot 1$ & 7.05 & 0.919 \\
\hline HEP & $-11 \cdot 3$ & $-15 \cdot 1$ & 6.32 & 0.588 \\
\hline \multicolumn{5}{|l|}{ Protein synthesis } \\
\hline $\mathbf{P D V}_{a_{1}}$ & $25 \cdot 8$ & $21 \cdot 5$ & $4 \cdot 72$ & 0.432 \\
\hline $\mathrm{PDV}_{\mathrm{y}, 1}$ & $32 \cdot 2$ & $27 \cdot 1$ & 6.08 & 0.465 \\
\hline $\mathrm{PDV}_{\mathrm{m}, \mathrm{v}}^{\mathrm{y}}$ & $25 \cdot 3$ & 21.9 & 4.84 & 0.530 \\
\hline HEP $_{\mathrm{g}}^{\mathrm{m}, \mathrm{v}}$ & $9 \cdot 3$ & 8.5 & $3 \cdot 41$ & 0.840 \\
\hline $\operatorname{HEP}_{\mathrm{y}}^{\mathrm{a}, \mathrm{l}}$ & $13 \cdot 0$ & $12 \cdot 1$ & $4 \cdot 67$ & 0.856 \\
\hline $\mathrm{HEP}_{\mathrm{m}, \mathrm{v}}^{\mathrm{v}, \mathrm{l}}$ & $9 \cdot 3$ & 8.6 & $3 \cdot 28$ & 0.839 \\
\hline \multicolumn{5}{|l|}{ Oxidation } \\
\hline PDV & $1 \cdot 3$ & $3 \cdot 3$ & 1.03 & $0 \cdot 143$ \\
\hline HEP & $4 \cdot 3$ & $5 \cdot 3$ & 1.92 & 0.659 \\
\hline
\end{tabular}

MOP, 4-methyl-2-oxo-pentanoate; PDV, portal-drained viscera; HEP, hepatic; SED, standard error of the difference between means.

* For details of procedures, see pp. 668-671.

$\uparrow$ Based on one-way analysis of variance, 3 residual degrees of freedom.

$\$$ Based on enrichment of arterial MOP; values in parentheses based on blood free leucine enrichment.

$\S$ Based on arterial ${ }^{13} \mathrm{CO}_{2}$ enrichment (adjusted to standard $\left[1-{ }^{13} \mathrm{C}\right]$ leucine infusion rate) and $\mathrm{CO}_{2}$ production determined by indirect calorimetry.

II Based on MOP (or leucine) flux - leucine oxidation and then corrected for leucine mass (131), content in body protein ( $66 \mathrm{~g}$ leucine $/ \mathrm{kg}$ body protein) and time.

II For details of calculations see pp. 670-671. The subscripts ${ }_{\mathrm{a}}$ and $\mathrm{v}$ refer to arterial and venous blood while $m$ and ${ }_{1}$ detail whether the calculations are based on MOP or leucine enrichments.

on the volumetric approach pioneered by Katz \& Bergman (1969b) tended to yield greater calculated arterial flows, due to a systematic bias associated with transfer and evaporative losses. To avoid such problems and generally to improve analytical precision gravimetric procedures were adopted for the present analysis and as a general approach throughout the study.

$\mathrm{O}_{2}$ consumptions across both the PDV and liver each contributed between 19 and $26 \%$ of whole-body values and although these were not significantly different between the treatments there was a trend towards higher values, particularly for liver, at the increased $\mathrm{NH}_{3}$ infusion (Table 1).

Initial tests had indicated that the $\mathrm{NH}_{4} \mathrm{Cl}$ loading would cause only a transient alteration in blood $\mathrm{pH}$ but for all four experimental animals there was a chronic depression, yielding mild acidosis, with an average decrease of $0.08 \mathrm{pH}$ units in arterial blood (Table 1). There was no consistent effect of the $\mathrm{NH}_{4} \mathrm{Cl}$ load on $\mathrm{pCO}_{2}$ but the calculated arterial plasma bicarbonate concentration was decreased substantially $(>5 \mathrm{~mm}$ ) in three of the sheep (Table 1). 


\section{Leucine kinetics}

Whole-body leucine flux was unaltered by the $\mathrm{NH}_{3}$ loading, as was estimated protein synthesis (Table 2). There was a significant increase, however, in the absolute amount of leucine oxidized at the higher $\mathrm{NH}_{3}$ infusion (Table 2). Net leucine PDV absorption, corrected for transfers between MOP and into $\mathrm{CO}_{2}$, was not altered by infusion of extra $\mathrm{NH}_{3}$ and slightly exceeded total leucine oxidation (Table 2), which would allow a small net anabolism. Net transfers of MOP across either the PDV or the liver did not exceed $\pm 1 \mu \mathrm{mol} / \mathrm{min}$ (results not shown). The contributions of the PDV and liver to total leucine oxidation were, on average, 12 and $25 \%$ respectively (Table 2 ). Approximately $50 \%$ of the apparent net absorbed leucine was removed across the liver and, of this, one-third was subsequently oxidized within the liver. Although none of these variables was significantly different between the two $\mathrm{NH}_{3}$ infusions, almost all of the difference in whole-body leucine oxidation could be accounted for by the increased catabolism across the splanchnic bed (Table 2).

Absolute rates of tissue protein synthesis, calculated from net disappearance of leucine label, depended on which metabolite enrichment was selected as most representative of the precursor for protein synthesis. Similar values were obtained when either arterial blood free leucine or venous blood MOP was selected but these were lower than the estimates based on venous blood free leucine (Table 2). Regardless of which was selected there were no significant differences in either GIT or liver protein synthesis as a result of additional infusion of $\mathrm{NH}_{3}$ (Table 2). Furthermore, hepatic protein synthesis was only $35-40 \%$ that of the PDV tissues.

\section{Amino acid transfers (Table 3)}

Arterial blood concentrations of circulating amino acids were unaltered by the two levels of $\mathrm{NH}_{4} \mathrm{Cl}$ infusion (results only shown for leucine; Table 2). Similarly, net PDV appearances were not different for either the essential or non-essential amino acids, and all amino acids except glutamine showed a positive appearance (i.e. net absorption). At the lower $\mathrm{NH}_{3}$ infusion, appearance of amino acid $\mathrm{N}$ in the portal vein was equivalent to $7.5 \mathrm{~g}$ $\mathrm{N} / \mathrm{d}$, approximately $42 \% \mathrm{~N}$ intake. Hepatic removal of total free amino acid- $\mathrm{N}$ was also not significantly different between the low and high $\mathrm{NH}_{3}$ treatments and represented $50 \%$ of the net absorption into the portal vein. Amino acids varied considerably as to the proportion absorbed that was removed by the liver; of the essentials, low extractions were observed for the branched chains and threonine but high for lysine, phenylalanine, histidine and methionine. Of the non-essential residues absorbed, alanine was almost completely extracted by the liver while there was net hepatic release of glutamate and aspartate.

\section{Urea and ammonia transfers (Table 4)}

PDV $\mathrm{NH}_{3}-\mathrm{N}$ flows, corrected for the amount of $\mathrm{NH}_{4} \mathrm{Cl}$ infused, were 427 (low) and 424 (high) $\mu \mathrm{mol} / \mathrm{min}$, equivalent to $8.6 \mathrm{~g} \mathrm{~N} / \mathrm{d}$ or $48 \%$ of apparent $\mathrm{N}$ intake. Urea was removed across the PDV at quantities of $56 \%$ and $50 \%$ of hepatic release at the low and high $\mathrm{NH}_{3}$ infusions respectively. If allowance is made for this additional $\mathbf{N}$ input into the GIT, $\mathrm{NH}_{3}$ appearance in the PDV would account for $10 \%$ of ingested $\mathrm{N}$. The $\mathrm{NH}_{3}-\mathrm{N}$ plus free amino acid- $\mathrm{N}$ appearance in the portal vein, at the lower $\mathrm{NH}_{3}$ infusion, accounted for $790 \mu \mathrm{mol} / \mathrm{min}$ and when this is corrected for the $352 \mu \mathrm{mol} / \mathrm{min}$ urea-N extracted into the GIT the remainder yields an apparent $\mathrm{N}$ digestibility of $0 \cdot 50$. This compares with a value of 0.54 observed with a similar diet previously (Nash et al. 1994) but the current calculation does not include other absorbed sources of $\mathrm{N}$, e.g. nucleic acids and amino sugars, which would increase the value. Arterial plasma concentrations of $\mathrm{NH}_{3}$ were greater than those in the hepatic vein, indicative of both peripheral tissue $\mathrm{NH}_{3}$ release and that hepatic removal of $\mathrm{NH}_{3}$ always slightly exceeded PDV appearance. 
AMMONIA KINETICS IN SHEEP

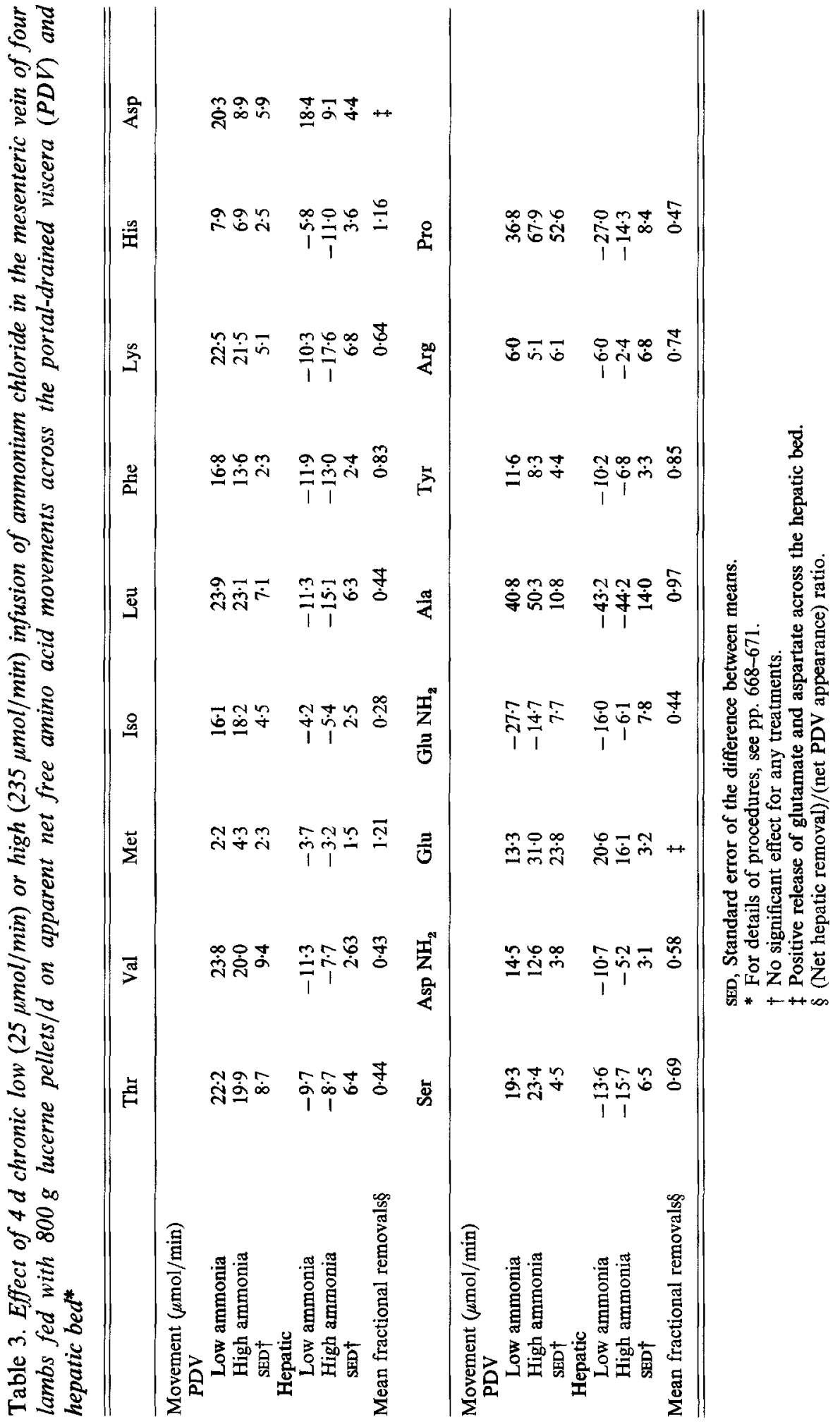


Table 4. Effect of $4 d$ chronic low $(25 \mu \mathrm{mol} / \mathrm{min})$ or high $(235 \mu \mathrm{mol} / \mathrm{min})$ infusion of ammonium chloride in the mesenteric vein of four lambs fed with $800 \mathrm{~g}$ lucerne pellets $/ \mathrm{d}$ on ammonia and urea transfers across the portal-drained viscera (PDV) and hepatic bed*

\begin{tabular}{|c|c|c|c|c|}
\hline Blood concentrations & Low $\mathrm{NH}_{\mathbf{3}}$ & High $\mathrm{NH}_{3}$ & SED & $P \dagger$ \\
\hline \multicolumn{5}{|l|}{ Ammonia $(\mu \mathrm{mol} / \mathrm{l})$} \\
\hline Arterial & 99 & 127 & $10 \cdot 6$ & 0.079 \\
\hline Portal vein & 379 & 505 & 15.0 & 0.003 \\
\hline Hepatic vein & 93 & 110 & 23.8 & 0.524 \\
\hline \multicolumn{5}{|l|}{ Urea $(\mathrm{mmol} /)$} \\
\hline \multicolumn{5}{|c|}{ Ammonia flows $(\mu \mathrm{mol} / \mathrm{min})$} \\
\hline $\begin{array}{l}\text { PDV } \\
\text { Hepatic }\end{array}$ & $\begin{array}{r}452 \\
-450\end{array}$ & $\begin{array}{r}659 \\
-664\end{array}$ & $\begin{array}{r}4 \cdot 7 \\
25 \cdot 4\end{array}$ & $\begin{array}{r}<0.001 \\
0.003\end{array}$ \\
\hline $\begin{array}{l}\text { Urea flows }(\mu \mathrm{mol} / \mathrm{min} \\
\text { PDV } \\
\text { Hepatic }\end{array}$ & $\begin{array}{r}-176 \\
314\end{array}$ & $\begin{array}{r}-258 \\
516\end{array}$ & $\begin{array}{r}123 \cdot 3 \\
73 \cdot 4\end{array}$ & $\begin{array}{l}0.544 \\
0 \cdot 071\end{array}$ \\
\hline \multicolumn{5}{|c|}{$\begin{array}{l}\text { Apparent hepatic } N \text { transfers } \\
\text { flows }(\mu \mathrm{mol} / \mathrm{min})\end{array}$} \\
\hline $\mathrm{NH}_{3} \mathrm{~N}+\mathrm{AA}-\mathrm{N}$ & 694 & 920 & $122 \cdot 1$ & $0 \cdot 161$ \\
\hline Urea-N & 628 & 1032 & $146 \cdot 7$ & 0.071 \\
\hline Balance & 65 & -134 & $96 \cdot 4$ & 0.130 \\
\hline
\end{tabular}

AA-N, amino acid nitrogen; SED, standard error of the difference between means.

* For details of procedures, see pp. 668-671.

$\dagger$ By one-way analysis of variance, 3 residual degrees of freedom.

Arterial blood concentrations of urea increased by $29 \%(P<0.02)$ during the high $\mathrm{NH}_{3}$ infusion. Concomitantly, hepatic release of urea-N was also increased $(+404 \mu \mathrm{mol} / \mathrm{min}$, $P=0.071$ ) by nearly twice the additional $\mathrm{NH}_{3}-\mathrm{N}$ extracted by the liver.

The sum of $\mathrm{NH}_{3}-\mathrm{N}$ and apparent free amino acid-N removal across the liver exceeded urea- $\mathrm{N}$ production during low $\mathrm{NH}_{3}$ infusion but there was an $11 \%$ deficiency when the $\mathrm{NH}_{3}$ load was increased.

\section{${ }^{15} N$ transfers}

During the course of the ${ }^{15} \mathrm{NH}_{3}$ infusion urea became progressively more enriched and by $10 \mathrm{~h}$ had still not achieved a 'plateau' value (Fig. 1). From the change in enrichment over the past $4 \mathrm{~h}$ a value for the biological half-life of just over $6 \mathrm{~h}$ was derived. Of the $\left[{ }^{15} \mathrm{~N}\right] \mathrm{urea}$ molecules synthesized at least $97 \%$ were as the single-labelled, i.e. $\left[{ }^{14} \mathrm{~N}^{15} \mathrm{~N}\right.$, form and the amounts of double-label $\left[{ }^{15} \mathrm{~N}^{15} \mathrm{~N}\right] \mathrm{urea}$ present were close to the detection limits of the GCMS. The majority of ${ }^{15} \mathrm{~N}$ recovered across the liver was as urea (93.5 (sE 0.8)\%) and over the last $4 \mathrm{~h}$ this exceeded (by $12 \%$ ) the amount of label infused as $\mathrm{NH}_{3}$ during the same period. This suggests that ${ }^{15} \mathrm{~N}$ recycling was occurring, possibly as labelled urea entering the GIT which is then reabsorbed as ${ }^{15} \mathrm{NH}_{3}$ or as $\left[{ }^{15} \mathrm{~N}\right]$ glutamine released from either the liver or muscle.

Some ${ }^{15} \mathrm{~N}$ was incorporated into free amino acids, but the enrichments for alanine, glycine, serine, aspartate and glutamate was less than 1 mpe (Table 5). Isotopic activity was elevated $(P<0.05)$ for alanine and glutamate under high $\mathrm{NH}_{3}$ administration. Glutamine showed the most substantial enrichments at both rates of $\mathrm{NH}_{3}$ administration but with $>95 \%$ as the single-label form. 


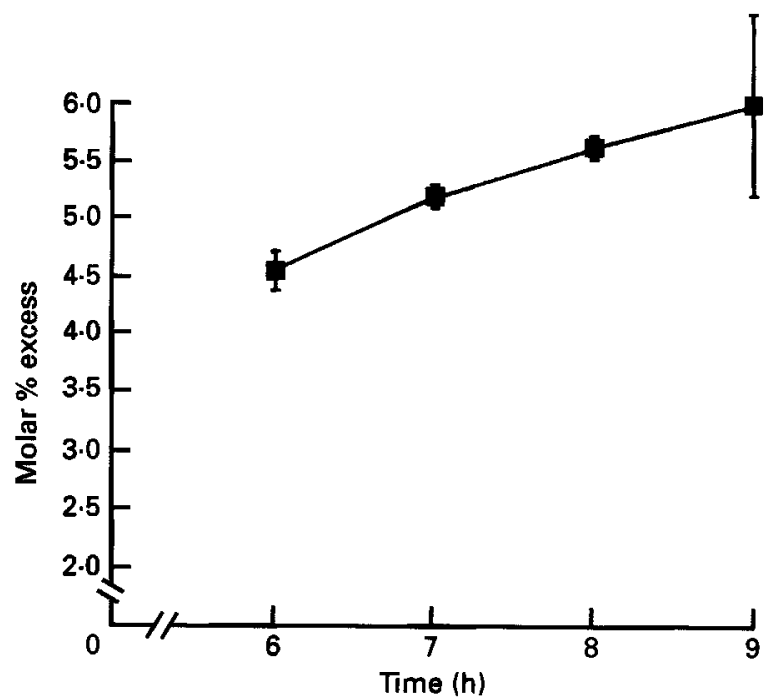

Fig. 1. Temporal changes in arterial urea molar \% excess during infusion of ${ }^{15} \mathrm{NH}_{3}$ into the mesenteric vein of four sheep. Values are means for high and low ammonia infusions combined $(n 8)$, with standard deviations indicated by vertical bars. For the first three time points data are normalized to the final time point values. For details of procedures, see pp. 668-671.

Table 5. Arterial amino acid enrichments (mpe) and net ${ }^{15} \mathrm{~N}$-transfers ( $\mathrm{umol}{ }^{15} \mathrm{~N} / \mathrm{min}$ ) across the portal-drained viscera (PDV) and liver of four sheep infused with either low $(25 \mu \mathrm{mol} / \mathrm{min})$ or high $(235 \mu \mathrm{mol} / \mathrm{min}$ ) ammonium chloride into the mesenteric vein for $4 \mathrm{~d}$ and offered $800 \mathrm{~g}$ lucerne pellets $/ d^{*}$

\begin{tabular}{|c|c|c|c|c|c|c|}
\hline & Alanine & Glycine & Serine & Aspartate & Glutamate & Glutamine \\
\hline \multicolumn{7}{|l|}{ Enrichments (mpe) } \\
\hline Low ammonia & 0.24 & 0.26 & 0.22 & 0.15 & $0 \cdot 38$ & 1.44 \\
\hline High ammonia & $0 \cdot 34$ & 0.34 & 0.42 & 0.22 & 0.64 & 3.05 \\
\hline SED & 0.029 & 0.078 & 0.045 & 0.079 & 0.081 & 0.468 \\
\hline$P_{\dagger}^{\dagger}$ & $0 \cdot 042$ & NS & $0 \cdot 067$ & NS & 0.052 & 0.041 \\
\hline \multirow{2}{*}{\multicolumn{7}{|c|}{$\begin{array}{l}{ }^{15} \mathrm{~N} \text {-transfers ( } \mu \mathrm{mol} \\
{ }^{15} \mathrm{~N} / \mathrm{min} \text { ) } \\
\text { PDV }\end{array}$}} \\
\hline & & & & & & \\
\hline Low ammonia & 0.040 & -0.156 & -0.042 & -0.017 & $0 \cdot 148$ & -0.788 \\
\hline High ammonia & 0.122 & -0.123 & -0.022 & 0.008 & $-0 \cdot 194$ & -0.325 \\
\hline SED & 0.032 & 0.941 & 0.020 & $0-028$ & $0-067$ & 0.142 \\
\hline$P+$ & $0 \cdot 014$ & NS & NS & NS & 0.053 & $0-047$ \\
\hline \multicolumn{7}{|l|}{ Liver } \\
\hline Low ammonia & -0.025 & 0.284 & 0.068 & 0.024 & 0.415 & $0 \cdot 104$ \\
\hline High ammonia & 0.028 & 0.582 & 0.139 & $0 \cdot 112$ & 0.863 & 1.887 \\
\hline SED & 0.015 & 0.195 & 0.054 & 0.052 & 0.298 & 0.968 \\
\hline$P+$ & NS & NS & NS & NS & NS & NS \\
\hline
\end{tabular}

SED, Standard error of the difference between means; NS, not significant.

* For details of procedures, see pp. 668-671.

$\dagger$ By one-way analysis of variance, 3 residual degrees of freedom.

Removal of $\left[{ }^{15} \mathrm{~N}\right]$ glutamine occurred across the PDV, in common with the net movements, but, in contrast, there was net output of labelled glutamine across the liver 


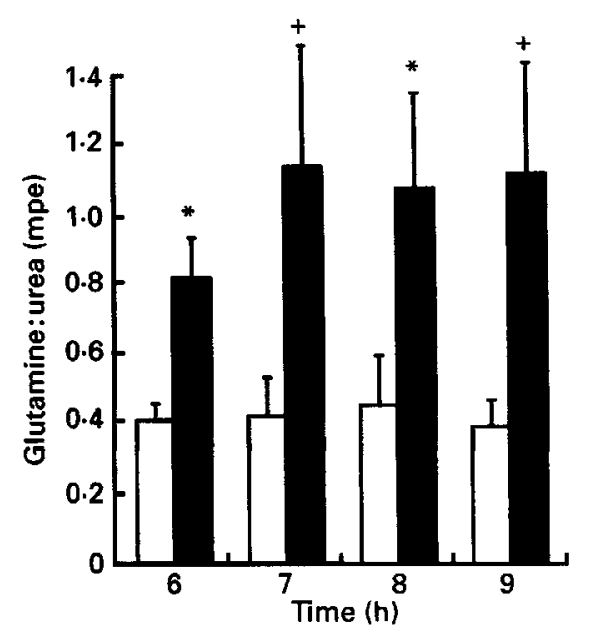

Fig. 2. Ratios of atom \% excess (mpe) enrichments of glutamine and urea from hepatic venous blood with time, during low $(25 \mu \mathrm{mol} / \mathrm{min}, \square)$ or high $(235 \mu \mathrm{mol} / \mathrm{min}, \square)$ infusions of ${ }^{15} \mathrm{NH}_{4} \mathrm{Cl}$ into the mesenteric vein of four sheep. Values are means $(n)$ with their standard errors indicated by vertical bars. ${ }^{*} P<0.05 ; \dagger P<0 \cdot 1$. For details of procedures, see pp. 668-671.

despite the net extraction (Table 5). The $\left[{ }^{15} \mathrm{~N}\right]$ glutamine hepatic release tended to be greater at the higher $\mathrm{NH}_{3}$ infusion (Table 5) but was not statistically significant. This was due primarily to low glutamine concentrations in the hepatic venous samples of one sheep on the lower $\mathrm{NH}_{3}$ infusion; this yielded a higher extraction for both net and labelled glutamine but may be due to breakdown of the amino acid on storage. A clearer picture of the increased flux through hepatic glutamine synthetase $(E C 6.3 .1 .2)$ is given by comparison of the enrichments of glutamine: urea in the hepatic vein where for each sheep at every time point the ratio was greater for the higher $\mathrm{NH}_{3}$ administration (average 2.5 (SE 0.2); Fig. 2). Although neither urea nor glutamine enrichments attained plateau within the infusion period the ratios of their enrichments had stabilized by the seventh hour of infusion.

\section{DISCUSSION}

Although hepatic detoxification of $\mathrm{NH}_{3}$ is often considered a problem peculiar to ruminants with their substantial foregut fermentation it is almost certainly a universal requirement because even in the laboratory rat $\mathrm{NH}_{3}$ concentrations in the portal vein are similar to those observed for ruminants (e.g. Cooper et al. 1987) and extensive extraction by the liver occurs in the human (e.g. Summerskill \& Wolpert, 1970). This detoxification will certainly have an effect on hepatic bioenergetics but whether there is an additional penalty on protein metabolism is open to debate. The current study attempts to address the consequences for both energy expenditure and amino acid availability to the periphery under circumstances where only $\mathrm{NH}_{3}$ supply is altered. One possible deficiency of the design adopted is that during chronic (4 d) infusion of $\mathrm{NH}_{3}$ there may be recycling of the additional products, particularly urea and glutamine, to the digestive tract which may alter protein and (or) energy supply. This is considered unlikely as amino acid absorption across the PDV was unaltered by $\mathrm{NH}_{3}$ infusion. The alternative approach was to monitor acute effects over a few hours but because these conditions may not establish a stable homeostatic or homeorhetic system this was rejected. 
Whole-body and splanchnic tissue protein and energy metabolism

In both sheep and cattle, energy expenditure, either measured directly or estimated from gaseous exchange, across the splanchnic tissues represents a substantial proportion of whole-body heat production. For example, for the ovine PDV estimates from 22 to $33 \%$ have been reported (Webster et al. 1975; Burrin et al. 1989; see Ortigues, 1991) and similar values are observed for cattle (e.g. Huntington, 1990; Reynolds et al. 1991 a). Although the proportion of whole-body energy expenditure attributable to the PDV does vary with intake (Webster et al. 1975; Burrin et al. 1989; see Huntington, 1990; Ortigues, 1991) it was unaffected by the additional $\mathrm{NH}_{3}$ infusion. The contribution of the liver to total $\mathrm{O}_{2}$ consumption matched that of the PDV, again in agreement with other observations (Huntington \& Reynolds, 1987; Burrin et al. 1989; Reynolds et al. 1991 a), but there was a trend for increased energy expenditure with the supplemental $\mathrm{NH}_{3}$. In cattle ureagenesis has been estimated to contribute $13-16 \%$ to liver energetics, based on the stoichiometric requirement of four high-energy phosphate bonds per mole urea synthesized and assuming six such bonds per mole $\mathrm{O}_{2}$ consumed (Huntington, 1989; Reynolds et al. 1991 b). Based on similar assumptions, under the conditions of low $\mathrm{NH}_{3}$ infusion ureagenesis represented a minimum of $13 \%$ of the ovine hepatic $\mathrm{O}_{2}$ demand; this value increased to $19 \%$ at the greater $\mathrm{NH}_{3}$ load. In terms of the incremental responses between the two rates of infusion, however, urea synthesis accounted for $45 \%$ of extra liver energy expenditure. When considering the effects of $\mathrm{NH}_{3}$ detoxification on hepatic bioenergetics these values must be considered as a minimum because additional costs will be associated with energy-requiring linked amination reactions involving, for example, GLDH and glutamine synthetase.

Even though the liver and PDV make substantial and similar contributions to wholebody energy expenditure differences exist with respect to protein metabolism. The arterio-venous leucine kinetics theoretically allow estimates to be made of protein synthesis and gain, and hence, by difference, protein breakdown. Although net isotope transfers can be quantified with reasonable accuracy, conversion into amino flows requires knowledge of the isotopic activity of the precursor pool for protein synthesis based on the enrichments of the intracellular leucyl-tRNA or nascent polypeptides from polysomes, measurements outwith the scope of the current project. The adopted use of the more-easily defined free amino acid pools involves an over-simplification because PDV and hepatic tissues produce both constitutive and export proteins synthesized in different compartments of the cell (e.g. Fern \& Garlick, 1974). Furthermore, protein synthetic activities vary considerably between the various components of the PDV tissues, from reticulo-rumen to colon, and between the structurally distinct serosal and mucosal layers (Attaix et al. 1987; Southorn et al. 1992; Lobley et al. 1994). Animals in the fed state can utilize amino acids for PDV tissue protein synthesis from both systemic (high enrichment) and luminal (low enrichment) sources and, thus, systemic infusion of labelled leucine will tend to underestimate protein synthesis rates. To unravel such complexities would require either use of terminal procedures (Attaix $e t$ al. 1987, 1992; Southorn et al. 1992; Lobley et al. 1994) or combined luminal and systemic infusion of isotope (e.g. Alpers, 1972; MacRae et al. 1993).

Nonetheless, despite these above considerations, the arterio-venous approach can offer a good comparative base. For example, the hepatic rates for protein synthesis $(8 \cdot 6-9 \cdot 3 \mu \mathrm{mol} / \mathrm{min})$, based on venous MOP enrichment, are slightly greater than weightadjusted values calculated from sheep studied using the large-dose procedure $(7 \cdot 3 \mu \mathrm{mol} /$ min; Lobley et al. 1994). This latter technique will yield an underestimate equivalent to the amount of synthesized protein exported within the measurement period. Thus, in practice, the two procedures may give close agreement. The observed contribution of hepatic synthesis to whole-body protein synthesis $(11 \%)$ also agrees well with other ruminant studies (Lobley et al. 1980; Attaix et al. 1987), although it is somewhat lower than the value 
derived from studies with mature ewes (Pell et al. 1986).

In contrast, the rates of protein synthesis determined across the PDV by the arterio-venous procedure are less than those observed in both younger and older lambs (Attaix et al. 1987; Lobley et al. 1994), probably due to the considerations discussed above. Despite this, the PDV protein synthesis rate exceeded that of the liver by approximately 2.5fold, similar to the near 3-fold difference observed by Attaix et al. (1987), again supporting the comparative strength of the approach.

What is clear, however, is that there was no significant change in whole-body protein synthesis nor in the absolute or proportional contribution from the PDV and liver as a consequence of increasing the $\mathrm{NH}_{3}$ load. In some respects this is not unexpected because even with considerable increases in intake both the liver and GIT sections show little or no alteration in fractional synthesis rate, in contrast to the situation with peripheral tissues (Lobley et al. 1992, 1994) and differences in absolute rate are associated more with changes in tissue protein mass (Burrin et al. 1990). GIT size is unlikely to be altered under the current experimental conditions.

\section{Amino acid transfers across the splanchnic tissues}

The rate of $\mathrm{NH}_{3}$ infusion did not affect net free amino acid absorption across the PDV and the values were similar to those observed previously for sheep at maintenance intake (Wolff et al. 1972; Heitmann \& Bergman, 1981). In these earlier reports, glutamine, probably produced by peripheral tissues, was removed by the PDV tissues, an effect noted in the current study. The enrichment of $\left[{ }^{15} \mathrm{~N}\right]$ glutamine produced was not lowered during passage across the PDV, indicating that net absorption from dietary sources or GIT metabolism was probably small.

In general the proportional extraction of the absorbed amino acids from blood by the liver followed the pattern reported by other workers for plasma removals (e.g. Wolff $e t$ al. 1972) with lower fractional rates of extraction $0.28-0.43$ for the branched-chain amino acids compared with methionine and the aromatic and basic residues. The major discrepancy relates to threonine of which, in the current study, less than 0.5 of that absorbed was removed by the liver compared with complete extraction in the earlier study (Wolff et al. 1972). Whether this relates to differences in diet, use of blood rather than plasma or technical difficulties is unclear.

Mass movements of amino acids across a tissue do not describe their fates which might involve either catabolism or anabolism and, for this reason, the alternative approach of measuring oxidation of an amino acid directly was adopted. While catabolism of most amino acids is confined primarily to the liver that of leucine, valine and isoleucine can occur within peripheral tissues, muscle and fat (Pell et al. 1986; Goodwin et al. 1987; Papet et al. 1988), as well as in the splanchnic region which accounted for $33-42 \%$ of the total in the current study. Changes in the latter appeared, however, to account for the increase in whole-body oxidation of leucine as a consequence of the higher $\mathrm{NH}_{3}$ infusion. Although it is tempting to ascribe such increases in oxidation to a direct provision of amino- $\mathrm{N}$ for the ornithine cycle to aid removal of the extra $\mathrm{NH}_{3}$, there is an alternative explanation based on the observation that in fasted humans, with similar chronic mild acidosis, leucine oxidation was stimulated (Reaich et al. 1992). They also observed, however, increases in both whole-body synthesis and breakdown which were not features of the current study. Furthermore, the response in humans was compared with observations in rats where acidosis was linked to increased muscle leucine catabolism, based on changes in the activity of the rate-limiting branched-chain oxoacid dehydrogenase (EC 1.2.4.4; May et al. 1987), whereas the current ovine data favour splanchnic tissue leucine oxidation. The contrary findings leave in doubt, therefore, whether the increased catabolism of the amino acid in 
the sheep is a response to acidosis or a means of providing additional substrate for $\mathrm{NH}_{3}$ removal. This can be tested by supplying $\mathrm{NH}_{3}$ in a form which does not change acid-base status.

\section{Hepatic ammonia and urea metabolism}

Based on the assumption that liver mass was $1.6 \%$ of live body weight at the intake offered (Lobley et al. 1994), the rates of hepatic $\mathrm{NH}_{3}$ clearance were 46-64 $\mu \mathrm{mol} / \mathrm{h}$ per $\mathrm{g}$ wet tissue, within the reported maximal values for ruminants of 70-90 $\mu \mathrm{mol} / \mathrm{h}$ per $\mathrm{g}$ wet tissue (Linzell et al. 1971; Symonds et al. 1981; Orzechowski et al. 1987) and thus peripheral hyperammonaemia was avoided. The maximum proportion of urea- $\mathrm{N}$ which could be derived from $\mathrm{NH}_{3}$ was 0.66 and 0.54 at the low and high infusions respectively, requiring in both instances major inputs from other $\mathrm{N}$ sources. This shortfall in substrate for urea$\mathrm{N}$ could, at the lower $\mathrm{NH}_{3}$ supplementation, be more than accommodated by the apparent hepatic extraction of free amino acid N. Indeed, extracted amino acid would be in theoretical excess sufficient to provide $66 \mu \mathrm{mol} \mathrm{N} / \mathrm{min}$ for synthesis of secreted proteins, equivalent to $35 \%$ of liver synthesis or $240 \mathrm{mg}$ export protein $/ \mathrm{kg}$ body weight per d, approximately double the amount required for albumin turnover in healthy adult human males (Ballmer et al. 1990).

With the greater $\mathrm{NH}_{3}$ administration, however, the increase in urea synthesis exceeded apparent uptake of $\mathrm{NH}_{3}-\mathrm{N}$ and free amino acid- $\mathrm{N}$ combined. Clearly, sufficient amino acid must be available to maintain net (export) protein synthesis by the liver and possibly alternative substrates, such as peptide material, may be utilized with, presumably, a net penalty to the $\mathrm{N}$ economy of the animal.

In other studies, the response of ruminants to direct $\mathrm{NH}_{3}$ addition has proved equivocal. Norton et al. (1982), for example, infused $0 \cdot 47 \mathrm{~mol} \mathrm{NH}_{4} \mathrm{Cl} / \mathrm{d}$ into the rumen of sheep and observed a non-significant decrease in $\mathbf{N}$ retention. In contrast, for cattle with acute mesenteric vein infusion of $\mathrm{NH}_{4} \mathrm{Cl}$ the additional urea- $\mathrm{N}$ produced exceeded the increment in hepatic $\mathrm{NH}_{3}$ removal by nearly 3-fold (Wilton et al. 1988). Although incomplete recovery of infused material was obtained in the latter study, the value is comparable with the incremental ratio of 1.9 obtained in the present experiment, and where reduced $\mathrm{N}$ retention would be predicted.

In certain dietary comparisons the hepatic uptake of $\mathrm{NH}_{3}$ can apparently account for $77-86 \%$ of urea-N appearance (e.g. Huntington, 1989; Maltby et al. 1991). When the hepatic $\mathrm{NH}_{3}$ removal: urea-N appearance ratio does exceed 0.5 then the possibility exists that both $\mathrm{N}$ atoms of urea may arise from $\mathrm{NH}_{3}$, probably through the actions of CPS and GLDH. It would therefore be predicted that following ${ }^{15} \mathrm{NH}_{3}$ administration $\left[{ }^{15} \mathrm{~N}^{15} \mathrm{~N}\right]$ and $\left[{ }^{15} \mathrm{~N}^{14} \mathrm{~N}\right]$ urea molecules will be formed. Nolan \& Leng (1972) infused $\left[{ }^{15} \mathrm{~N}\right]$ ammonium sulphate into the rumen of sheep and observed that only $40-50 \%$ of the urea formed arose from ruminal $\mathrm{NH}_{3}$, similar to the proportion of total $\mathrm{NH}_{3}$ production: urea synthesis. In the current study only 55-65\% of urea-N synthesis could be equated with hepatic $\mathrm{NH}_{3}$ extraction and the labelled urea molecules formed were predominantly $\left[{ }^{14} \mathrm{~N}^{15} \mathrm{~N}\right] \mathrm{species}$, which suggests that channelling of $\mathrm{NH}_{3}-\mathrm{N}$ simultaneously through the CPS and GLDH pathways has not occurred. In theory, GLDH can operate in both the forward and reverse directions but under controlled nutritional and physiological conditions one would be favoured, and if it is accepted that the action of mitochondrial enzyme is towards oxaloacetate formation, with the provision of $\mathrm{NH}_{4}^{+}$for carbamoyl phosphate synthesis (Lowenstein, 1972; Nissim et al. 1992), then transfer of ${ }^{15} \mathrm{~N}$ from $\mathrm{NH}_{3}$ to aspartate via glutamate would be limited, and $\left[{ }^{15} \mathrm{~N}^{15} \mathrm{~N}\right]$ urea would not be synthesized. Thus, rat hepatocytes incubated with $\left[5-{ }^{15} \mathrm{~N}\right]$ glutamine, to generate $\mathrm{NH}_{3}$ via mitochondrial glutaminase $(E C 3.5 .1 .2)$ action, produced only $\left[{ }^{15} \mathrm{~N}^{14} \mathrm{~N}\right]$ urea while both $\left[2-{ }^{15} \mathrm{~N}\right]$ glutamine 
and $\left[2-{ }^{15} \mathrm{~N}\right]$ glutamate produced both $\left[{ }^{14} \mathrm{~N}^{15} \mathrm{~N}\right]$ and $\left[{ }^{15} \mathrm{~N}^{15} \mathrm{~N}\right]$ urea (Nissim et al. 1992). The incubation conditions employed in vitro do not necessarily stimulate the normal physiological and nutritional state of the rodent in vivo, and therefore the direction of GLDH action, because in fed, but anaesthetized, rats there was extremely rapid equilibration of labelled $\mathrm{N}$ from ${ }^{13} \mathrm{NH}_{3}$ to glutamate and aspartate (Cooper et al. 1987), conditions which should favour formation of doubly-labelled urea.

In the sheep enrichments of glutamate in the hepatic vein exceeded those of both the portal vein and aortal blood, indicative of formation of labelled glutamate either from $\mathrm{NH}_{3}$ and oxaloacetate and (or) by transamination reactions in the liver. That this did not lead to formation of $\left[{ }^{15} \mathrm{~N}^{15} \mathrm{~N}\right]$ urea may be a consequence of liver architecture. Periportal hepatocytes are the predominant cell type and are the site of both gluconeogenesis and ureagenesis. These cells also contain glutaminase and release, but do not extract, glutamate. In rodents, perivenous cells, which surround the hepatic vein, do not synthesize urea or glucose but have present the appropriate $\mathrm{Na}^{+}$-dependent $\mathrm{X}-\mathrm{AG}$ transporter, required for both aspartate and glutamate uptake (Gebhardt \& Mecke, 1983; Haussinger \& Gerok, 1983). In addition, the perivenous hepatocyte can synthesize glutamate (Sies \& Haussinger, 1984) from oxoglutarate and other tricarboxylate intermediates removed from the blood (Stoll \& Haussinger, 1989, 1991). If a similar situation pertains in sheep then the site of glutamate uptake and synthesis is downstream from the ureagenic cells and this would inhibit the formation of $\left[{ }^{15} \mathrm{~N}^{15} \mathrm{~N}\right]$ urea.

\section{Hepatic glutamine metabolism}

There was net removal of glutamine during passage across the liver, and this probably contributed to the hepatic net appearance of glutamate. The substantial increase in enrichment of glutamine across the liver clearly demonstrates the existence of the hepatic intercellular glutamine cycle, in which amino acid is first removed from the blood and hydrolysed by mitochondrial glutaminase in the periportal cells followed by reformation in the perivenous region through the action of cytosolic glutamine synthetase (Haussinger, 1983; Haussinger et al. 1992). The magnitude of the cycle could not be assessed from the current study as only net movements were monitored and there are uncertainties concerning both the quantity of portal-vein-derived glutamine removed and the enrichments of $\mathrm{NH}_{3}$ within the periportal and perivenous cells.

Although the nature of the predominant single-labelled glutamine produced by the liver could not be defined under the mass spectrometry conditions employed because the enrichment exceeded that of glutamate by two to four times it is presumed that the majority is as the [5-N]- rather than [2-N]-species, i.e. the amido group is labelled through the action of glutamine synthetase. This interpretation does depend on establishment of an equilibrium for free glutamate between blood and the efflux from intrahepatocyte sources (Haussinger \& Gerok, 1984). The role that the glutamine synthetase pathway plays in $\mathrm{NH}_{3}$ detoxification is exemplified by the doubling in the ratio of isotopic activities of glutamine: urea between the two rates of $\mathrm{NH}_{3}$ infusion. The urea cycle is a high-capacity, low-affinity system and removes the majority of $\mathrm{NH}_{3}$ entering from the portal vein, the periportal reaction being aided by the high initial $\mathrm{NH}_{3}$ concentration (Haussinger et al. 1992). In rodents glutamine synthetase has a tenfold lower $K_{\mathrm{m}}$ for $\mathrm{NH}_{3}$ than does CPS (Meijer et al. 1985) but is restricted to the perivenous cells, which comprise less than $10 \%$ of total hepatocytes (see Jungermann \& Katz, 1989; Haussinger et al. 1992), and thus provides a high-affinity, low-capacity scavenging system and ensures $\mathrm{NH}_{3}$ in hepatic venous blood entering the posterior vena cava is maintained at low concentrations. Under the current experimental conditions less than $4 \%$ of net ${ }^{15} \mathrm{~N}$ transfer across the ovine liver 
was as glutamine, a value similar to that observed for rat liver in vivo (7\%; Cooper et al. 1987). The additional $\mathrm{NH}_{3}$ was provided at a uniform rate and under circumstances where transient but higher rates of $\mathrm{NH}_{3}$ absorption may occur, e.g. fresh forage, silage, the action of hepatic glutamine synthetase may become more important.

\section{Conclusion}

The current study has shown that in response to an increased $\mathrm{NH}_{3}$ load ovine hepatic ureagenesis is stimulated with a requirement for additional $\mathrm{N}$ substrates. No evidence of increased free amino acid removal across the liver was observed although catabolism of leucine appeared to be stimulated. At least $50 \%$ of urea production was related to $\mathrm{NH}_{3}$ detoxification and the effects on both the energy and $\mathrm{N}$ metabolism of the sheep are substantial. Nutritional circumstances which lead to considerable absorption of $\mathrm{NH}_{3}$ from GIT fermentations may then inflict a double penalty in that, first, a proportion of feed-N is not made available to the animal as an anabolic form and, second, hepatic removal of the $\mathrm{NH}_{3}$ may require net utilization of ingested amino acids.

The analysis of ammonia and urea concentrations by Miss M. Annand is gratefully recognized. This work was funded by the Scottish Office Agriculture and Fisheries Department as part of the Core budget to the Rowett Research Institute.

\section{REFERENCES}

Alpers, D. H. (1972). Protein synthesis in intestinal mucosa: the effect of route of administration of precursor amino acids. Journal of Clinical Investigation 51, 167-173.

Atkinson, D. E. \& Bourke, E. (1984). The role of ureagenesis in $\mathrm{pH}$ homeostasis. Trends in Biochemical Sciences 9, 297-300.

Attaix, D., Aurousseau, E., Bayle, G., Manghebati, A. \& Arnal, M. (1987). Protein synthesis and degradation in growing lambs. In 5 th International Symposium on Protein Metabolism and Nutrition. European Association of Animal Production Publication, no. 35, pp. 24-27. Rostock: Wilhelm-Pieck University.

Attaix, D., Aurousseau, E., Rosolowska-Huszez, D., Bayle, G. \& Arnal, M. (1992). In vivo longitudinal variations in protein synthesis in developing ovine intestines. American Journal of Physiology 263, R1318-R1323.

Ballmer, P. E., McNurlan, M. A., Milne, E., Heys, S. D., Buchan, V., Calder, A. G. \& Garlick, P. J. (1990). Measurement of albumin synthesis in humans : a new approach employing stable isotopes. American Journal of Physiology 259, E797-E803.

Bartels, H. \& Harms, H. (1959). Saverstoffdissoziationskurven des Blutes von Säugetieren (Mensch, Karinchen, Meerschweinchen, Hund, Katz, Schwein, Rind und Schaf) (Oxygen dissociation curves for blood of mammals (man, rabbit, guinea pig, dog, cat, pig, cattle and sheep). Pfïgers Archivs 268, 334-365.

Blaxter, K. L., Brockway, J. M. \& Boyne, A. W. (1972). A new method for estimating the heat production of animals. Quarterly Journal of Experimental Physiology 57, 60-72.

Burrin, D. G., Ferrell, C. L., Britton, R. A. \& Bauer, M. (1990). Level of nutrition and visceral organ size and metabolic activity in sheep. British Journal of Nutrition 64, 439-448.

Burrin, D. G., Ferrell, C. L., Eisemann, J. H., Britton, R. A. \& Nienaber, J. A. (1989). Effect of level of nutrition on splanchnic blood flow and oxygen consumption in sheep. British Journal of Nutrition 62, 23-34.

Cooper, A. J. L., Nieves, E., Coleman, A. E., Filc-De Ricco, S. \& Gelbard, A. S. (1987). Short-term metabolic fate of [ $\left.{ }^{13} \mathrm{~N}\right] \mathrm{ammonia}$ in rat liver in vivo. Journal of Biological Chemistry 262, 1073-1080.

Fern, E. B. \& Garlick, P. J. (1974). The specific radioactivity of the tissue free amino acid pool as a basis for measuring the rate of protein synthesis in the rat in vivo. Biochemical Journal 142, 413-419.

Fitch, N. A., Gill, M., Lomax, M. A. \& Beever, D. E. (1989). Nitrogen and glucose metabolism by the liver of forage- and forage-concentrate-fed cattle. Proceedings of the Nutrition Society 48, 76A.

Fleet, I. R. \& Mepham, T. B. (1983). Physiological methods used in the study of mammary substrate utilisation in ruminants. In Biochemistry of Lactation, pp. 469-491 [T. B. Mepham, editor]. Amsterdam: Elsevier Science Publishers.

Gebhardt, R. \& Mecke, D. (1983). Glutamate uptake by cultured rat hepatocytes is mediated by hormonally inducible sodium-dependent transport systems. FEBS Letters 161, 275-278.

Goodwin, G. W., Gibboney, W., Paxton, R., Harris, R. A. \& Lemons, J. A. (1987). Activities of branch-chain amino acid aminotransferase and branch-chain 2-oxo dehydrogenase complex in tissues of maternal and fed sheep. Biochemical Journal 242, 305-308.

Harris, P. M., Skene, P. A., Buchan, V., Calder, A. G., Anderson, S. E., Connell, A. \& Lobley, G. E. (1992). Effect 
of food intake on hind-limb and whole-body protein metabolism in young growing sheep: chronic studies based on arterio-venous techniques. British Journal of Nutrition 68, 389-407.

Häussinger, D. (1983). Hepatocyte heterogeneity in glutamine and ammonia metabolism and the role of an intracellular glutamine cycle during ureogenesis in perfused rat liver. European Journal of Biochemistry 133, 269-274.

Häussinger, D. \& Gerok, W. (1983). Hepatocyte heterogeneity in glutamate uptake in isolated perfused rat liver. European Journal of Biochemistry 136, 421-425.

Häussinger, D. \& Gerok, W. (1984). Regulation of hepatic glutamate metabolism. Role of 2-oxoacids in glutamate release from isolated perfused rat liver. European Journal of Biochemistry 143, 491-497.

Häussinger, D., Lamers, W. H. \& Moorman, A. F. M. (1992). Hepatocyte heterogeneity in the metabolism of amino acids and ammonia. Enzyme 46, 72-93.

Heitmann, R. N. \& Bergman, E. N. (1981). Glutamate interconversions and glucogenicity in the sheep. American Journal of Physiology 241, E465-E472.

Herd, J. A. \& Barger, A. C. (1964). Simplifed technique for chronic catheterisation of blood vessels. Journal of Applied Physiology 19, 791-792.

Huntington, G. B. (1989). Hepatic urea synthesis and site and rate of removal from blood of beef steers fed alfalfa or a high concentrate diet. Canadian Journal of Animal Science 69, 215-223.

Huntington, G. B. (1990). Energy metabolism in the digestive tract and liver of cattle: influence of physiological state and nutrition. Reproduction, Nutrition, Developpement 30, 35-47.

Huntington, G. B. \& Reynolds, C. K. (1987). Oxygen consumption and metabolite flux of bovine portal-drained viscera and liver. Journal of Nutrition 117, 1167-1173.

Jungerman, K. \& Katz, N. (1989). Functional specialization of different hepatocyte populations. Physiological Reviews 69, 708-764.

Katz, M. L. \& Bergman, E. N. (1969a). A method for simultaneous cannulation of the major splanchnic blood vessels of the sheep. American Journal of Veterinary Research 30, 655-661.

Katz, M. L. \& Bergman, E. N. (1969b). Simultaneous measurements of hepatic and portal venous blood flow in the sheep and dog. American Journal of Physiology 216, 946-952.

Linzell, J. L., Setchell, B. P. \& Lindsay, D. B. (1971). The isolated perfused liver of sheep: assessment of its metabolic, synthetic and secretory functions. Quarterly Journal of Experimental Physiology 56, 53-71.

Lobley, G. E. (1992). Control of the metabolic fate of amino acids in ruminants: a review. Journal of Animal Science 70, 3264-3275.

Lobley, G. E., Connell, A., Milne, E., Newman, A. M. \& Ewing, T. A. (1994). Protein synthesis in splanchnic tissue of sheep offered two levels of intake. British Journal of Nutrition 71, 3-12.

Lobley, G. E., Harris, P. M., Skene, P. A., Brown, D., Milne, E., Calder, A. G., Anderson, S. E., Garlick, P. J., Nevison, I. \& Connell, A. (1992). Responses in tissue protein synthesis to sub- and supra-maintenance intake in young growing sheep: comparison of large-dose, and continuous-infusion techniques. British Journal of Nutrition 68, 373-388.

Lobley, G. E., Milne, V., Lovie, J. M., Reeds, P. J. \& Pennie, K. (1980). Whole body and tissue protein synthesis in cattle. British Journal of Nutrition 43, 491-502.

Lowenstein, J. M. (1972). Ammonia production in muscle and other tissues: the purine nucleotide cycle. Physiological Reviews 52, 382-414.

MacRae, J. C., Lobley, G. E., Bruce, L. A., Luo, Q. J., Calder, A. G. \& Farningham, D. A. H. (1993). Leucine kinetics across the portal drained viscera of sheep. Journal of Animal Science, Suppl. 71 1, 279 (Abstr.).

Maltby, S. A., Lomax, M. A., Beever, D. E. \& Pippard, C. J. (1991). The effect of increased ammonia and amino acid supply on post prandial portal-drained viscera and hepatic metabolism in growing steers fed maize silage. In Energy Metabolism of Farm Animals, European Association for Animal Production Publication, no. 58, pp. 20-33 [C. Wenk and M. Boessinger, editors]. Zurich: Schriftenreche aus dem Institut für Nutztierwissenschaften Gruppe Ernährung.

Marsh, W. H., Fingerhut, B. \& Miller, H. (1965). Automated and manual direct methods for the determination of blood urea. Clinical Chemistry 2, 624-627.

May, R. C., Hara, Y., Kelly, A., Block, K. P., Buse, M. G. \& Mitch, W. E. (1987). Branched chain amino acid metabolism in rat muscle: abnormal regulation in acidosis. American Journal of Physiology 252, E712-E718.

Meijer, A. J., Lamers, W. H. \& Chamuleau, R. A. F. M. (1990. Nitrogen metabolism and ornithine cycle function. Physiological Reviews 70, 701-748.

Meijer, A. J., Lof, C., Ramos, I. C. \& Verhoeven, A. J. (1985). Control of ureogenesis. European Journal of Biochemistry 148, 189-196.

Mondzac, A., Erlich, G. E. \& Seegmiller, J. E. (1965). An enzymatic determination of ammonia in biological fluids. Journal of Laboratory and Clinical Medicine 66, 526-531.

Nash, J. E., Rocha, H. J. G., Buchan, V., Calder, A. G., Milne, E., Quirke, J. F. \& Lobley, G. E. (1994). The effect of acute and chronic administration of the $\beta$-agonist, cimaterol, on protein synthesis in ovine skin and muscle. British Journal of Nutrition 71, 501-513. 
Nissim, I., Cattano, C., Nissim, I. \& Yudkoff, M. (1992). Relative role of the glutaminase, glutamate dehydrogenase, and AMP-deaminase pathways in hepatic ureagenesis: studies with ${ }^{15} \mathrm{~N}$. Archives of Biochemistry and Biophysics 292, 393-401.

Nissim, T., Yudkoff, M. \& Segal, S. (1985). Metabolism of glutamine and glutamate by rat renal tubules. Journal of Biological Chemistry 260, 13955-13967.

Nolan, J. V. \& Leng, R. A. (1972). Dynamic aspects of ammonia and urea metabolism in sheep. British Journal of Nutrition 27, 177-194.

Norton, B. W., Janes, A. N. \& Armstrong, D. G. (1982). The effects of intraruminal infusions of sodium bicarbonate, ammonium chloride and sodium butyrate on urea metabolism in sheep. British Journal of Nutrition 48, 265-274.

Ortigues, I. (1991). Adaptation of energy metabolism to under-nutrition in ruminants. Quantification in whole animal and individual body tissues. Reproduction, Nutrition, Developpement 31, 593-616.

Ortigues, I., Durand, D. \& Lefaivre, J. (1994). Use of para-amino hippuric acid to measure blood flow through portal-drained-viscera, liver and hindquarters in sheep. Journal of Agricultural Science, Cambridge 122, 299-308.

Orzechowski, A., Motyl, T., Pierzynowski, G. \& Barej, W. (1987). Hepatic capacity for ammonia removal in sheep. Journal of Veterinary Medicine A 34, 108-112.

Papet, I., Lezebot, N., Barre, F. \& Arnal, M. (1988). Influence of dietary leucine content on the activities of branched-chain amino acid transferase $(E C 2.6 .2,42)$ and branched-chain $\alpha$-keto acid dehydrogenase (EC 1.2.4.4) complex in tissues of pre-ruminant lambs. British Journal of Nutrition 59, 475-483.

Pell, J. M., Calderone, E. M. \& Bergman, E. N. (1986). Leucine and $\alpha$-ketoisocaproate metabolism and interconversions in fed and fasted sheep. Metabolism 35, 1005-1016.

Reaich, D., Channon, S. M., Scrimgeour, C. M. \& Goodship, T. H. J. (1992). Ammonium chloride-induced acidosis increases protein breakdown and amino acid oxidation in humans. American Journal of Physiology 263, E735-E739.

Reynolds, C. K. \& Tyrrell, H. F. (1991). Effects of mesenteric vein L-alanine infusion on liver metabolism in beef heifers fed on diets differing in forage: concentrate ratio. British Journal of Nutrition 66, 437-450.

Reynolds, C. K., Tyrrell, H. F. \& Reynolds, P. J. (1991a). Effects of diet forage-to-concentrate ratio and intake on energy metabolism in growing beef steers: whole body energy and nitrogen balance and visceral heat production. Journal of Nutrition 121, 994-1003.

Reynolds, C. K., Tyrrell, H. F. \& Reynolds, P. J. (1991b). Effects of diet forage-to-concentrate ratio and intake on energy metabolism in growing beef heifers : net nutrient metabolism by visceral tissues. Journal of Nutrition 121, 1004-1015.

Sies, H. \& Häussinger, D. (1984). Hepatic glutamine and ammonia metabolism. Nitrogen balance and intercellular glutamine cycle. In Glutamine Metabolism in Mammalian Tissues, pp. 78-97 [D. Häussinger and H. Sies, editors]. Berlin: Springer.

Siggaard-Anderson, O. (1974). The Acid-Base Status of Blood, 4th ed. Copenhagen: Munksgaard.

Smith, H. W., Finkelstein, N., Aliminosa, L., Crawford, B. \& Graber, M. (1945). The renal clearances of substituted hippuric acid derivatives and other aromatic acids in dogs and man. Journal of Clinical Investigation 24, 388-404.

Southorn, B. G., Kelly, J. M. \& McBride, B. W. (1992). Phenylalanine flooding dose procedure is effective in measuring intestinal and liver protein synthesis in sheep. Journal of Nutrition 122, 2398-2407.

Stoll, B. \& Häussinger, D. (1989). Functional hepatocyte heterogeneity: vascular 2-oxoglutarate is almost exclusively taken up by perivenous glutamine-synthetase-containing hepatocytes. European Journal of Biochemistry 181, 709-716.

Stoll, B. \& Häussinger, D. (1991). Hepatocyte heterogeneity in uptake and metabolism of malate and related dicarboxylates in perfused rat liver. European Journal of Biochemistry 195, 121-129.

Summerskill, W. H. J. \& Wolpert, E. (1970). Ammonia metabolism in the gut. American Journal of Clinical Nutrition 23, 633-639.

Symonds, H. W., Mather, D. L. \& Collis, K. A. (1981). The maximum capacity of the bovine liver to metabolize ammonia. Proceedings of the Nutrition Society 40, 63A.

Turnell, D. C. \& Cooper, J. D. H. (1982). Rapid assay for amino acids in serum or urine by pre-column derivatization and reversed-phase liquid chromatography. Clinical Chemistry 28, 527-531.

Webster, A. J. F., Osuji, P. O., White, F. \& Ingram, J. F. (1975). The influence of food intake on portal blood flow and heat production in the digestive tract of sheep. British Journal of Nutrition 34, 125-139.

Wilton, J. C., Gill, M. \& Lomax, M. A. (1988). Uptake of ammonia across the liver of forage-fed cattle. Proceedings of the Nutrition Society 47, 153A.

Wolff, J. E., Bergmann, E. N. \& Williams, H. H. (1972). Net metabolism of plasma amino acids by liver and portal-drained viscera of fed sheep. American Journal of Physiology 223, 438-446. 